\title{
Couvelaire uterus
}

\author{
Manju Rathi, ${ }^{1}$ Sunil Kumar Rathi, ${ }^{2}$ Manju Purohit, ${ }^{3,4}$ Ashish Pathak ${ }^{2,5}$
}

1 Department of Obstetrics and Gynecology, RD Gardi Medical College, Ujiain, Madhya Pradesh, India

${ }^{2}$ Department of Peadiatrics, RD Gardi Medical College, Ujjain, Madhya Pradesh, India

${ }^{3}$ Department of Pathology, RD Gardi Medical College, Ujjain, Madhya Pradesh, India

${ }^{4}$ Department of Public Health Sciences, Global Health (IHCAR), Stockholm, Sweden ${ }^{5}$ Department of Women and Children's Health, International Maternal and Child Health (IMCH) Unit, Uppsala University, Uppsala, Sweden

\section{Correspondence to} Dr Ashish Pathak, drashishp@rediffmail.com

Accepted 27 February 2014

To cite: Rathi M, Rathi SK, Purohit M, et al. BMJ Case Rep Published online:

[please include Day Month Year] doi:10.1136/bcr-2014204211

\section{DESCRIPTION}

A 23-year-old primiparous woman with 37 weeks of amenorrhoea was admitted to the Obstetric ward with symptoms of severe abdominal pain and non-progression of labour past $20 \mathrm{~h}$. The patient was registered for antenatal care at a peripheral health centre (PHC). She had two previous antenatal visits at the PHC. Her last visit was 15 days prior to admission, during which her blood pressure was found to be normal. In her second trimester visit, her blood group was B positive, haemoglobin was found to be $8.5 \mathrm{~g} / 100 \mathrm{~mL}$, urine routine showed no pathological findings and the tests for venereal disease research laboratory (VDRL) and HIV were non-reactive. She had no history of diabetes mellitus or hypertension and had not undergone any surgeries in the past.

On admission, she was afebrile, heart rate 130/ min, blood pressure $94 / 60 \mathrm{~mm} \mathrm{Hg}$ in supine position in the left upper limb and respiratory rate was $20 /$ min. Significant pallor was noted (haemoglobin of $8.5 \mathrm{~g} / 100 \mathrm{~mL}$ ). The total leucocyte count was $12.5 \times 10^{9} / \mathrm{L}$ (reference range $4-11 \times 10^{9} / \mathrm{L}$ ) with neutrophilia $9.1 \times 10^{9} / \mathrm{L}$ (reference range 2.5$7.5 \times 10^{9} / \mathrm{L}$ ). Her coagulation profile was normal, bleeding time $4 \mathrm{~min}$ (reference range 3-10 $\mathrm{min}$ ), clotting time $3 \mathrm{~min}$ (reference range $2-6 \mathrm{~min}$ ) and prothrombin time $12 \mathrm{~s}$ (reference range 1-18 s).

On per abdomen examination, there was uterine tenderness and the uterus did not relax between contractions. On admission, the fetal heart rate was $160 \mathrm{bpm}$ but significant decelerations $(<100 \mathrm{bpm})$ were noted within $30 \mathrm{~min}$ of admission. Per vaginal examination revealed fresh bleeding from the uterine cavity. The cervix was $3 \mathrm{~cm}$ long and $2 \mathrm{~cm}$ dilated. Partial placental detachment from the lower uterine cavity was noted. The placenta was completely covering the internal os, a finding suggestive of central placenta praevia. A clinical diagnosis of cephalopelvic disproportion was also made. An emergency lower segment caesarean section was performed for non-progression of labour due to cephalopelvic disproportion with central placenta praevia with significant fetal distress.

On entering the uterine segment, a complete abruption of placenta was noted. A male child weighing $2.6 \mathrm{~kg}$ was delivered. The baby cried immediately after birth. On inspection, the uterus was found to have dark purple patches with ecchymosis and indurations diagnostic of Couvelaire uterus or uteroplacental apoplexy (figure $1 \mathrm{aA}, \mathrm{B}) .{ }^{1-3}$ The haemorrhage is seen to infiltrate the lateral portions of uterus. A retroplacental clot with estimated blood loss of $2 \mathrm{~L}$ was also noted. The patient was transfused $200 \mathrm{~mL}$ of packed cells during the surgery and two more transfusions of $200 \mathrm{~mL}$ of packed cells were given in the postoperative period. She was given cefazolin $1 \mathrm{gm}$ every 8 hours for 5 days in view of leucocytosis. The rest of her postoperative stay was normal.

Couvelaire $^{1}$ first described the entity in 1911. It is a rare non-fatal complication of severe abruption. ${ }^{23}$ It is estimated to complicate $5 \%$ of all cases of abruption. ${ }^{2}$ The entity is infrequently reported and the incidence is difficult to estimate because the diagnosis is made by direct visualisation or biopsy. $^{2}{ }^{3}$

Couvelaire uterus is caused when haemorrhage from placental blood vessels seeps into decidua basalis causing placental separation, followed by infiltration in the lateral portions of the uterus. ${ }^{3}$ Occasionally, the infiltrations reach the peritoneal cavity. Couvelaire uterus is managed conservatively. ${ }^{3}$ Hysterectomy is not required and should be discouraged.
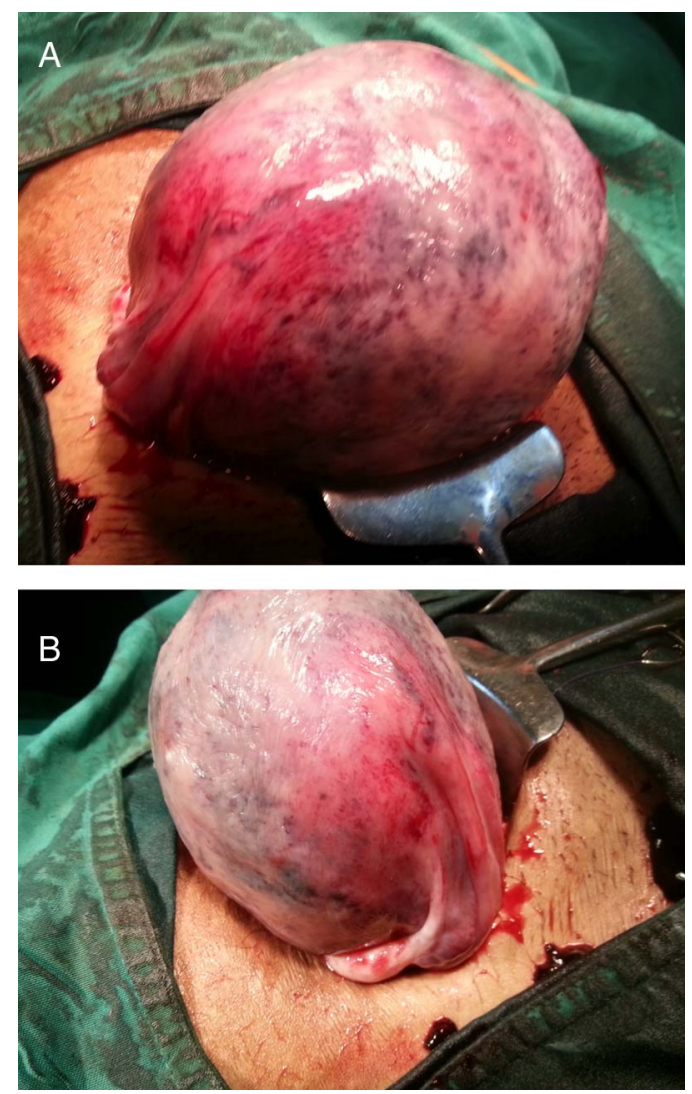

Figure $1(A, B)$ The dark purple and copper colour patches with ecchymosis and indurations diagnostic of Couvelaire uterus or uteroplacental apoplexy. Haemorrhagic infiltration in the lateral portions of the uterus is also seen. 
Acknowledgements The authors thank Dr JK Sharma, the Dean of RD Gard Medical College, Ujiain, Madhya Pradesh, India and Medical Director Dr VK Mahadik for giving permission to publish this case.

Contributors MR and SKR collected the clinical details and photographs. AP performed the literature review, wrote the draft and revised the manuscript. MR, SKR, MP and AP verified the diagnosis and other scientific facts. All authors are responsible for clinical follow-up of the case and read and approved the final version of the manuscript.

Competing interests None.

Patient consent Obtained.

Provenance and peer review Not commissioned; externally peer reviewed.

\section{REFERENCES}

1 Couvelaire A. Deux nouvelles observations d'apoplexie utero-placentaire (hemorrhagies retro-placentaires avec infiltration sanguine de la pavoi musculaire de l'uterus). Ann Gynecol Obstet 1912;9:486.

2 Habek D, Selthofer R, Kulas T. Uteroplacental apoplexy (Couvelaire syndrome). Wien Klin Wochenschr 2008:120:88

3 Hubbard JL, Hosmer SB. Couvelaire uterus. J Am Osteopath Assoc 1997;97:536-7.

Copyright 2014 BMJ Publishing Group. All rights reserved. For permission to reuse any of this content visit http://group.bmj.com/group/rights-licensing/permissions.

BMJ Case Report Fellows may re-use this article for personal use and teaching without any further permission.

Become a Fellow of BMJ Case Reports today and you can:

- Submit as many cases as you like

- Enjoy fast sympathetic peer review and rapid publication of accepted articles

- Access all the published articles

- Re-use any of the published material for personal use and teaching without further permission

For information on Institutional Fellowships contact consortiasales@bmjgroup.com

Visit casereports.bmj.com for more articles like this and to become a Fellow 